\title{
Fertility, Family Policy and Welfare Regimes
}

\author{
Elina Schleutker
}

\begin{abstract}
This paper is inspired by the many similarities between gendered welfare state research and demographic research on the determinants of fertility. The first part of the paper discusses some of the theories on childbearing in the light of the gendered welfare state theory. One important similarity between these two genres is that when work-life choices are studied, the emphasis is on policies which enable women to reconcile employment and family. Support for informal care is accordingly treated as having a negative influence on work-life compatibility, and women are moreover assumed to have homogeneous preferences, i.e., they are supposed to want to combine work and family. However, such an approach does not pay sufficient attention to informal care and to heterogeneity among women, either when it comes to preferences or to behaviour. To address these gaps, in the second part of the paper a new framework to analyse women's work-life choices is developed. The suggested framework gives considerable attention to the way in which formal as well as informal care is supported or enforced in different welfare states and the consequences such support has on women's decision making. Moreover, heterogeneity among women is emphasised, both in preferences and when it comes to behaviour. The central argument is that women's heterogeneous preferences transform differently to different lifestyle career strategies (with regard to employment and childbearing) in different welfare state settings, as each lifestyle strategy is encouraged or discouraged by family policy to differing degrees. Hence, the number of women who choose a particular strategy, as well as the level of fertility, varies between the welfare states. In addition, household resources are assumed to influence the choices that are being made. The argument that is put forward is illustrated with recent data on family policy, women's employment patterns and fertility in the social-democratic (Denmark, Finland, Norway, Sweden), conservative (Austria, Belgium, France, Germany, Greece, Italy, the Netherlands, Portugal, Spain) and liberal welfare states (Australia, Canada, Ireland, the UK, the USA). Moreover, a reinterpretation of the findings on the relationship between family policy, female employment and fertility is provided in the light of the framework outlined.
\end{abstract}

Keywords: Fertility · Family policy · Preferences 


\section{Introduction}

For a welfare state researcher, a quick look at total fertility rates (TFR) in the developed countries probably awakens thoughts of the striking resemblance between the welfare regime types and levels of period fertility: In general, the liberal and social democratic regimes experienced relatively high fertility during 1990-2010 (1.7-2.1), whereas the conservative regimes have struggled with low (below 1.5) or lowestlow (below 1.3) fertility. ${ }^{1}$ However, there are some exceptions to this general rule. Most notably, fertility rates in Canada have been somewhat lower than in the other liberal countries. TFR in Belgium, France and the Netherlands has been only somewhat below or at the same levels as in the liberal and social democratic countries, and finally in Sweden the fertility rates have fluctuated radically, and occasionally approached the 1.5 limit (OECD 2012).

Given the similarities between the welfare state types and levels of fertility, it is not surprising that a number of scholars engaged in the gendered ${ }^{2}$ welfare state study discuss the possibility that some welfare state arrangements have an impact on childbearing (e.g. Esping-Andersen 1999; Bettio/Plantenga 2004; De Henau et al. 2006; Fagnani 2007). During the past decades, the influence of family policy on fertility has also been examined by demographers to an increasing extent (see section 3 below). The question of whether and how family policy can influence fertility rates is naturally also of interest to decision makers, who in many countries are worried about sub-replacement fertility levels (UN 2010:7) and wish to take action to increase childbearing (for Germany, see Henninger et al. 2008). However, despite the extensive discussion on the matter, our understanding of the relationship between family policy and fertility is still somewhat limited (Gauthier 2007; Neyer 2011).

In contemporary discussions the recipe for high fertility is often claimed, by both welfare state researchers and by demographers, to be generous family policy which enables the reconciliation of work and family (see sections 2 and 3). Such an approach nevertheless ignores two important issues: Firstly, women have heteregeneous preferences, varying from home-centeredness to work-centeredness, and women with different preferences will respond differently to different social policies (Hakim 1998, 2000, 2002, 2003a/b). Secondly, the concentration on policies which enable the reconciliation of work and family ignores the role of informal care, the cross-country variation in welfare state support it receives as well as the many changes that have taken place in this sphere (Pfau-Effinger 2004, 2005).

This paper focuses on the relationship between family policy and fertility, and has two aims. Firstly, as the many similarities between gendered welfare state research and research on fertility call for a comparison between these fields, after a short review of the gendered welfare state theories (section 2) we discuss how demographers can learn from gendered research on the welfare state (section 3). Secondly, a suggestion of how Hakim's preference theory and feminist research on

1 See section 4.1 for the list of countries included in each cluster.

2 "Gendered" and "feminist" are used as synonyms here. 
the welfare state can be combined into a new framework is put forward (section 4). The central argument made in the paper is that women's heterogeneous preferences transform differently to different lifestyle career strategies (with regard to employment and childbearing) in different welfare state settings, as each lifestyle strategy is encouraged or discouraged by family policy to different degrees, and in addition influenced by household resources. Consequently, the number of women who choose a particular strategy, as well as the level of fertility, varies between the welfare states. These claims are illustrated with recent data on family policy, women's employment patterns and fertility in social-democratic (Denmark, Finland, Norway, Sweden), conservative (Austria, Belgium, France, Germany, Greece, Italy, the Netherlands, Portugal, Spain) and liberal countries (Australia, Canada, Ireland, the UK, the USA). In addition, a brief reinterpretation of the findings on the relationship between family policy, female employment and fertility is provided (section 5). The paper ends with concluding remarks (section 6).

\section{Women, families and welfare regimes}

A useful starting point for a review of gendered welfare state research is provided by the intensive critique which Esping-Andersen (1990) received from feminist scholars after he had put forward his argument about the tripartite welfare regime typology. Esping-Andersen's well known key idea is that there are qualitative differences between the welfare states and that these differences can be analysed with help of three different indicators. Firstly, the extent of de-commodification (i.e. welfare state protection of workers who are unable to earn their living on the labour market) varies between the welfare states. Secondly, there are cross-country differences concerning the most important provider of welfare in terms of state, market and family. Thirdly, due to the differences in the degree of de-commodification and the interplay between state, market and family, different welfare states promote different patterns of social stratification. The dissimilarities between the welfare states, analysed along these three dimensions, permit the countries to be classified into three clusters, each characterised by its own logic. In the Northern European social democratic regimes, the state is the major actor when it comes to decommodification. The benefits are generous and universal, and the system tends to create social equality among citizens. In turn, the liberal Anglo-Saxon regimes only allot a minimal role to the state and rely heavily on market-based solutions, such as private insurance. The market-based practices, combined with a low degree of de-commodification through the state, mainly to the very marginalised groups (means testing), maintain the socioeconomic differences between those who can afford market-based welfare and those who cannot. A third type of de-commodification is put into practice in the Western and Southern European conservative welfare regimes, where the state and the family take on the major responsibility. De-commodification is provided based on the occupational status, and its extent varies accordingly, so that the system maintains the prevailing work-related status composition of the people. 
This elegant classification of welfare states initiated a vivid discussion (for methodological problems in Esping-Andersen's work, see Obinger/Wagschal 1998; for a review, see Arts/Gelissen 2002). In particular, feminist researchers accused EspingAndersen of having based his classification on male standards and of leaving women and the family outside the analysis. Indeed, the worker whom Esping-Andersen has in mind is one with market employment and, consequently, de-commodification is not relevant for the large amount of women who work at home and are not commodified. Further, unpaid household work is also done by women who are in market employment, but as this kind of work is excluded from Esping-Andersen's conceptualisation, the typology unavoidably ignores the family as a provider of care and welfare. It is also worth noting that many housewives are not dependent on the labour market, but on their husbands, and their relation with the welfare state is defined through their roles as mothers and/or wives (not as workers). Finally, women and families are treated differently in different welfare states, and hence welfare state arrangements do not only have an impact on the socioeconomic stratification, as suggested by Esping-Andersen, but also on gender relations (Lewis 1992; Orloff 1993; Ostner 1995; Anttonen/Sipilä 1996; Sainsbury 1994; and for a review, Lewis 1997). In other words, the feminist critique concentrates on unpaid care work (e.g. Daly/Lewis 2000), which was largely ignored in Esping-Andersen's presentation.

As a result of the feminist critique, Esping-Andersen (1999) integrated the family dimension into his typology with two new concepts, "familialism" (state and market non-provision of welfare services) and "de-familialization" 3 (the extent to which the welfare burden of the family is eased through state or market provision of services, or/and through the arrangements within the family). According to EspingAndersen, the high degree of familialism in the conservative countries discourages female employment, whereas de-familialization in the social demcoratic countries enables women to become commodified. These new concepts do not change the original typology of the three welfare regime types, although Esping-Andersen acknowledges that there are some differences between the Continental and Southern European countries. Most notably, the degree of de-familialization by the state and within the family is lower in the Continental European countries, child benefits are lower in the Southern European countries and, finally, the tax and transfers system in the Continental European countries creates disincentives for the second earner's employment, whereas this is not the case in the Southern European countries.

Even Esping-Andersen's gendered framework is sometimes claimed to be unsatisfactory (Knijn/Ostner 2002; Pfau-Effinger 2004, 2005; Woods 2006; Leitner/Lessenich 2007). In particular, Leitner (2003) puts forward a more nuanced framework of familialism and emphasises the fact that the state can either support the family in its caring function (familialization) or ease the welfare responsibilities of the family (de-familialization). Further, in Leitner's framework the magnitude of familialization and de-familialization can be either strong or weak, which results in four differ-

3 Originally introduced to the research vocabulary by Lister (1994) and McLaughlin/Glendinning (1994). 
ent combinations of familialism. However, instead of improving Esping-Andersen's conceptualisations, many scholars have concentrated on the creation of completely new frameworks. Lewis and Ostner for example distinguish between three different types of breadwinner regimes, namely strong, modified and weak (Lewis 1992; Ostner 1995). Further, Pfau-Effinger $(2004,2005)$ emphasises the interaction between institutions and cultural factors and distinguishes between the dual breadwinner family model and the modernised male breadwinner model. Finally, some studies classify countries based on how they cluster when a particular statistical method is applied (Thévenon 2011).

The results of the above studies in terms of the countries belonging to the different clusters are found in Table 1. As can be read from the table, the number of clusters varies from three to five and has remained relatively stable during the past two decades. In general, the Nordic as well as the Anglo-Saxon countries and the Continental European countries together with the Southern European countries, form one group each. There are some exceptions from this rule. Some studies have found Belgium and France to be more similar to the Nordic than to the Continental European countries (Leitner 2003; Pfau-Effinger 2005), or they are even distinguished constituting a separate cluster (Lewis 1992; Ostner 1995). Southern European countries are likewise sometimes clustered into a separate cluster which is distinct from the Continental European countries due to the limited support for informal care (Leitner 2003; Thévenon 2011, but see also Esping-Andersen 1999). Moreover, in two cases the UK is classified together with the Continental European countries which are biased towards informal care (Lewis 1992, Ostner 1995; PfauEffinger 2005), and one of these studies (Pfau-Effinger 2005) also finds that Norway displays certain similarities with the Continental European countries.

In this context, it is important to remember that concentration on the general cross-country differences can sometimes overlook the many goals of family policy. Thévenon (2011) for example distinguishes between six different aims, namely poverty reduction and income maintenance, direct compensation for the economic costs of children, promotion of employment, promotion of gender equity, support for early childhood development and increasing fertility. These aims are adopted to differing degrees in different welfare state regimes, which also translates to the differences in the actual policies. For instance, gender equity and women's employment are given the key role in the Northern European welfare states, whereas Anglo-Saxon countries prioritise poverty reduction and income maintenance. Furthermore, the different policy goals may clash, which can result in inconsistencies. In Austria and Germany, for example, the reconciliation of work and family is to a certain extent supported by parental leave regulations, but at the same time the daycare system is underdeveloped since it has traditionally served the goal of early education (Leitner/Wroblewski 2006).

In addition to the country groupings and studies on social policy, many feminist scholars have contributed to the research by evaluating the gender stratification of the welfare state and social policy against the standards of woman-friendliness (Hernes 1987/1989; for critique see Borchorst/Siim 2008), gender equality and gender equity. In these contributions the welfare state is often considered to be the cen- 
Tab. 1: Family policy clusters

\begin{tabular}{|c|c|c|c|c|c|}
\hline & I & II & III & IV & $\mathbf{V}$ \\
\hline $\begin{array}{l}\text { Lewis (1992), } \\
\text { Ostner (1995) }\end{array}$ & $\begin{array}{c}\text { Weak } \\
\text { breadwinner: } \\
\text { Denmark } \\
\text { Finland } \\
\text { Sweden }\end{array}$ & $\begin{array}{c}\text { Moderate } \\
\text { breadwinner: } \\
\text { Belgium } \\
\text { France }\end{array}$ & $\begin{array}{l}\text { Strong } \\
\text { breadwinner: } \\
\text { Germany } \\
\text { Ireland } \\
\text { Netherlands } \\
\text { UK }\end{array}$ & & \\
\hline \multirow[t]{2}{*}{$\begin{array}{l}\text { Esping-Andersen } \\
\text { (1999) }\end{array}$} & $\begin{array}{c}\text { Social- } \\
\text { democratic: }\end{array}$ & & \multicolumn{2}{|c|}{ Conservative: } & \\
\hline & $\begin{array}{l}\text { Denmark } \\
\text { Finland } \\
\text { Norway } \\
\text { Sweden }\end{array}$ & $\begin{array}{l}\text { Australia } \\
\text { Canada } \\
\text { Ireland } \\
\text { UK } \\
\text { USA }\end{array}$ & $\begin{array}{l}\text { Continental } \\
\text { Europe } \\
\text { Austria } \\
\text { Belgium } \\
\text { France } \\
\text { Germany } \\
\text { Netherlands }\end{array}$ & $\begin{array}{c}\text { Southern } \\
\text { Europe } \\
\text { Italy } \\
\text { Portugal } \\
\text { Spain }\end{array}$ & \\
\hline $\begin{array}{l}\text { Leitner (2003) } \\
\text { (childcare only) }\end{array}$ & $\begin{array}{c}\text { Optional } \\
\text { familialism: } \\
\text { Belgium } \\
\text { Denmark } \\
\text { Finland } \\
\text { France } \\
\text { Sweden }\end{array}$ & $\begin{array}{c}\text { Explicit } \\
\text { familialism: } \\
\text { Austria } \\
\text { Germany } \\
\text { Italy } \\
\text { Luxembourg } \\
\text { Netherlands }\end{array}$ & $\begin{array}{c}\text { De-familialism: } \\
\text { Ireland } \\
\text { UK }\end{array}$ & $\begin{array}{c}\text { Implicit } \\
\text { familialism: } \\
\text { Greece } \\
\text { Portugal } \\
\text { Spain }\end{array}$ & \\
\hline $\begin{array}{l}\text { Pfau-Effinger } \\
(2005)\end{array}$ & $\begin{array}{l}\text { France } \\
\text { Denmark } \\
\text { Sweden } \\
\text { Finland }\end{array}$ & $\begin{array}{l}\text { Modernisation of } \\
\text { the male } \\
\text { breadwinner } \\
\text { model: } \\
\text { UK } \\
\text { Norway } \\
\text { Netherlands } \\
\text { Western Germany }\end{array}$ & & & \\
\hline Thévenon (2011) & $\begin{array}{l}\text { Continuous } \\
\text { strong support } \\
\text { for working } \\
\text { parents of } \\
\text { children under } \\
\text { age 3: } \\
\text { Denmark } \\
\text { Finland } \\
\text { Iceland } \\
\text { Norway } \\
\text { Sweden }\end{array}$ & $\begin{array}{l}\text { High financial } \\
\text { support, but } \\
\text { limited support } \\
\text { for dual-earner } \\
\text { families with } \\
\text { children under } \\
\text { age 3: } \\
\text { Austria } \\
\text { Belgium } \\
\text { France } \\
\text { Germany } \\
\text { Luxembourg } \\
\text { Netherlands }\end{array}$ & $\begin{array}{l}\text { Short leave, } \\
\text { support targeted } \\
\text { to low-income } \\
\text { single parent } \\
\text { families and } \\
\text { families with } \\
\text { preschool } \\
\text { children: } \\
\text { Australia } \\
\text { Canada } \\
\text { Ireland } \\
\text { New Zealand } \\
\text { Switzerland } \\
\text { UK } \\
\text { USA }\end{array}$ & $\begin{array}{l}\text { Limited } \\
\text { assistance for } \\
\text { families: } \\
\text { Greece } \\
\text { Italy } \\
\text { Korea } \\
\text { Japan } \\
\text { Portugal } \\
\text { Spain }\end{array}$ & $\begin{array}{c}\text { Long leave } \\
\text { but low cash } \\
\text { benefits and } \\
\text { childcare for } \\
\text { children } \\
\text { under age 3: } \\
\text { Czech Republic } \\
\text { Hungary } \\
\text { Poland } \\
\text { Slovakia }\end{array}$ \\
\hline
\end{tabular}

tral actor which either encourages or discourages gender equity (Mazur 2002: 15). It is common that three different definitions of gender equity are applied. Probably the most profound argumentation on the issue is that provided by Fraser (1994), who discusses the types of gender equity along the lines of what she chooses to call the "universal breadwinner model", where gender equity is striven for by promoting female employment, and the "caregiver parity model", where gender equity is promoted by supporting informal care work. Fraser herself concludes that neither 
of the models is good enough as they do not require men to change and, consequently, she claims that gender equity can be achieved only when men become more like women, i.e., when men also combine care-giving and employment. In practice, according to Pfau-Effinger (2004, 2005), a somewhat evolutionary view of gender equity has dominated the research, that is a high proportion of public childcare and female labour force participation (high degree of de-familialization) is seen as the woman-friendly and gender-equal alternative, whereas a low share of public child care and female employment (high degree of familialism) is understood as less women-friendly and gender equal. Pfau-Effinger herself has criticised this approach by pointing out that there is evidence of several different paths which are taken to gender equity, and that the one-dimensional frameworks (such as familialization and de-familialization) are not adequate to capture current welfare state developments.

\section{What lessons can demographers learn from gendered research on the welfare state?}

In order to exemplify how demographers can benefit from gendered welfare state research, this section compares the theories discussed above on the welfare state with two types of theories on fertility, namely the economic theory on fertility and gender equity and role incompatibility theories.

\subsection{New home economics and welfare state institutions}

The economic theory on fertility treats children as consumer durables and analyses household demand for children with the same tools as demand for any other durable. In this framework, the number of children is assumed to depend on a household's preferences, the quality and quantity of children, household income and the costs of children (Becker 1960; Becker/Lewis 1973; Willis 1973; Becker 1981/1991). Women's employment and thus their opportunity costs are in turn often presumed to influence fertility negatively. That is, the higher education and income, the higher the opportunity costs and the lower fertility.

The importance of this theory for fertility research has been vast, but one of its drawbacks is that it ignores the fact that choices are made in national institutional contexts which differ substantially, as discussed above. Consequently, it is probable that the economic theory, or at least research based on the theory, would benefit if the knowledge of gendered welfare state research were taken into account when it comes to the differences between the institutional logics in the treatment of the family. Many scholars already refer to welfare state literature when they make hypotheses or interpret the results (e.g. Köppen 2006; Brodmann et al. 2007). However, a more extensive discussion of the institutional constraints in different countries would enable more systematic context-specific hypothesising, and therefore also allow systematic predictions about the influence of the central variables on fertility in different types of welfare states. 
It is, for example, well known that women's inactivity influences fertility positively at micro-level (Hoem/Hoem 1989; Berinde 1999; Oláh 2003; Cooke 2004; Kreyenfeld 2004; Prskawetz/Zagaglia 2005; Cooke 2008; Breton/Prioux 2009). As the direction of the impact is well established, the possible differences in the magnitude of the effect should be discussed. The descriptive evidence provided by feminist scholars concerning the welfare state support for informal care could prove to be helpful here. A possible hypothesis could be, for instance, that in countries where the male breadwinner family is generously supported (e.g. Germany), the household income of families where the woman is inactive, and hence the fertility is higher, than in countries where practically no support is provided for male breadwinner families (e.g. Sweden). Other areas where the gendered welfare state theories might help in a similar manner to increase our understanding of the magnitude of the influence are for instance the negative impact of educational attainment on first births (Kreyenfeld 2004; Klein/Eckhard 2007; Westoff/Marshall 2010), and the mixed evidence of the impact of female income, varying from negative (Rønsen 2004; Rondinelli et al. 2010) to positive (Hoem 2000; Andersson 2000; Vikat 2004) and even U-shaped (Kreyenfeld/Zabe/ 2005) depending on the country and parity that are studied. With a similar logic, considerations of the interaction between welfare state institutions might help researchers to explain why certain variables sometimes behave contrary to expectations. For example, the weak support for the impact of family policy on fertility (Gauthier 2007) might be better understood by paying more attention to the welfare state institutions and especially to the consistency of family policies (e.g. Leitner/Wroblewski 2006).

\subsection{Role compatibility, gender equity and de-familialization}

The change in the macro-level association between female labour force participation and fertility from negative to positive in the mid-1980s (Ahn/Mira 2002; Rindfuss et al. 2003; but see also Castles 2003) inspired several scholars to theorise about the influence of family policy on fertility and women's employment. For instance, Rindfuss and Brewster (1996), Brewster and Rindfuss (2000) and Rindfuss et al. (2003) argue that, whereas governments in some countries are better at implementing policies that reduce role incompatibility between market employment and parenthood, institutions in other countries have not adapted to the labour force participation of mothers. According to them, high role incompatibility leads to low participation and low fertility, whereas role compatibility leads to both high participation and high fertility. McDonald (2000a/b, 2002), in turn, claims that the size of the gap between gender equity in family-oriented institutions (institutions which deal with people as family members, such as joint taxation) and individual-oriented institutions (institutions which treat people as individuals, such as education and labour market) determines the level of fertility. According to $M c$ Donald, the levels of gender equity in the individual-oriented institutions are high at present in all developed countries. Those countries in which gender equity in the family-oriented institutions is likewise high have the highest fertility, whereas those countries where the degree of gender equity in family-oriented institutions is lower, experience lower levels of fertility. 
There are several parallels between these theories on fertility and Esping-Andersen's framework on familialization and de-familialization, which is also recognised by the authors themselves (Rindfuss et al. 2003: 415; McDonald 2000a: 1, 2002: 429). Indeed, role compatibility and gender equity are basically de-familialization in disguise: In all theories, family policy which eases the welfare responsibilities of the family is identified as a key determinant of high fertility. Consequently, a very similar critique as that which has been targeted towards the concept of de-familialization can be targeted towards the role incompatibility thesis, as well as to gender equity theory. For example, all three theories in essence exemplify Pfau-Effinger's (see section 2) description of an evolutionary approach to social policy where the changes in informal care and different developmental paths of the welfare states are ignored and the focus is instead placed on the ways in which the different countries support women's labour market participation. As I see it, the minor attention given to informal care and to the ways in which it is organised considerably weakens the analytical power of the frameworks discussed above. To put it differently, the theories do not take into consideration that a low degree of role compatibility and gender equity might mean completely different things in different countries, and that this might in turn have different consequences for fertility. Moreover, the increases in role compatibility and gender equity can take different paths, each of which might influence fertility differently.

Tab. 2: Leitner's (2003) framework on familialism

\begin{tabular}{|c|c|c|}
\hline \multirow[t]{2}{*}{ Familialization } & \multicolumn{2}{|c|}{ De-familialization } \\
\hline & Strong & Weak \\
\hline Strong & Optional familialism & Explicit familialism \\
\hline Weak & De-familialism & Implicit familialism \\
\hline
\end{tabular}

Source: Table 1 in Leitner (2003: 358).

One way to understand these difficulties which arise from the lack of a profound consideration of informal care is to consider these theories in the light of the framework of Leitner (2003) discussed above. To briefly repeat the argument, Leitner distinguishes between strong and weak defamilialization and familialization, respectively. This distinction results in a framework in which family policy can be classified into four different types (Table 2): Strong familialization and strong de-familialization (optional familialism), weak de-familialization, but strong familialization (explicit familialism), strong de-familialization, but weak familialization (de-familialism), and weak familialization and weak de-familialization (implicit familialism).

If the arguments put forward by the supporters of the role incompatibility thesis, and by McDonald, are considered in the light of Leitner's framework, it is not very clear what, for example, a low degree of role compatibility and a low degree of gender equity in family-oriented institutions mean. In this case, are we dealing with explicit or implicit familialism, or with both alternatives? After all, the degree of role compatibility and gender equity in the family-oriented institutions is low in both 
cases, yet in the first case the state supports the family in its caring function (explicit familialism), whereas in the other case the state lets the family survive on its own resources (implicit familialism). A classic example here would be the low degree of childcare provision in the conservative welfare states (weak defamilialiazation), but generous tax support for male breadwinner families as well as in generously compensated long leave periods, for example in Germany (strong familialization), and the lack of such tax support and shorter, poorly-compensated leave periods in Greece (weak familialization). Despite the common denominator of a low degree of role compatibility, defamilialization and gender equity, it appears logical that fertility is affected differently by family policy in these two countries.

The same logic applies to the rising level of de-familialization: The theories of role incompatibility and gender equity assume that any increase in the degree of role compatibility or gender equity in the family-oriented institutions leads towards higher fertility. Yet it is not clear whether the increases in the level of de-familialization, on the one hand, or familialization, on the other, influence fertility differently, or do so to differing degrees. For example: An increase in childcare supply increases the level of role compatibility and gender equity in family-oriented institutions (strong defamilialization), but does this increase influence fertility in a similar way and to a similar extent as an increase in parental leave periods and compensation (strong familialization)?

These problems naturally do not challenge the core claims made by the supporters of these theories as to the positive impact of generous reconciliation policies on fertility. However, a further specification of these theories might result in a better understanding of the causal mechanisms between family policy and fertility, and thus of the cross-country differences in fertility.

\section{$4 \quad$ Towards an integrated approach}

The introduction of the gendered welfare state perspective on demographic theories on childbearing can probably contribute to a better understanding of fertility behaviour. However, even though the theoretical frameworks on fertility discussed above have significantly increased our understanding of the influence of micro and macro level factors on fertility, none of them has provided us with a comprehensive explanation of the variations in fertility between the countries. Thus, it is reasonable to ask whether a further step should be taken towards a combined theory. One of the many possibilities to take an integrated approach is outlined below. The suggestion of combining elements from both sides of the research is not new, but comparable considerations have been articulated for example by McDaniel (1996), Neyer (2006), as well as by González and Jurado-Guerrero (2006). The approach taken in this paper differs from the earlier attempts in that it also introduces women's heterogeneous preferences and systematically discusses the way in which these preferences in different welfare states transform into different choices in terms of employment and family. 


\subsection{From preferences to career strategies}

According to the preference theory by Hakim $(1998,2000,2002,2003 a / b)$, women today have better possibilities to lead the kind of life they want, due to several historical changes which have contributed to a new scenario (contraceptive revolution, equal opportunities revolution, expansion of white-collar occupations, employment opportunities for secondary earners, and the increasing importance of attitudes, values and personal preferences when it comes to the choices made about lifestyle). Consequently, both the variation in women's fertility and labour market participation can be explained with the heterogeneity in women's lifestyle preferences when it comes to employment and childbearing.

Hakim further argues that it is possible to distinguish between three different groups of women based on their preferences: The majority group (40-80 percent of the female population) consists of adaptive women who either wish to combine work and family without giving priority to either of them, or have unplanned careers and drift in a sense that they do not have a clear idea of how they want to lead their lives. These women are highly responsive for example to employment and social policy, as these policies influence working conditions and the degree of role compatibility. A minority of women (10-30 percent of the female population) are home-centred. The primary aspiration of these women is to devote themselves to homemaking, and they usually have large families. Their employment choices are not affected by employment policy (as they prefer not to work, at least not when their children are young), but their fertility is partly determined by social policy, as it influences family income, which in turn influences fertility. Finally, another minority group of women (also 10-30 percent of the female population) is work-centred. For these women, work is their first priority and they only have children, if it is possible in the context of their work. Consequently, and contrary to the other two groups of women, workcentred women are not very responsive to social or family policy. The sizes of the preference groups vary between the countries, as the policies normally support one group of women at the expense of the others. This, according to Hakim, is also the reason for low fertility; when women are not supported in their preferred lifestyles by the government, they have fewer children than they would like to have.

The preference theory is found to be problematic, both when it comes to theory and practice. Several researchers have, for example, accused Hakim of ignoring the fact that preferences alone do not explain women's employment patterns but that women's work orientations are a sum of nationally and culturally different opportunities and constraints (Crompton/Harris 1998a/b; McRae 2003a/b). Furthermore, Pfau-Effinger (2004) has pointed out that Hakim has not made it clear why women choose different labour market careers than their preferences would suggest, as well as why different types of preference have evolved in the first place, and why an individual woman chooses one preference group over the others. Moreover, at the theoretical level it is difficult to draw a demarcation line between the different preference groups (McRae 2003a: 333), whereas at practical level it has proven to be difficult to distinguish between the groups using the existing survey material (Hakim 2003c). The studies support the idea that preferences have an impact on 
women's employment patterns at least to some extent, but the interplay between preferences and constraints (Doorewaard et al. 2004; Crompton/Lyonette 2005; Kan 2007; Kangas/Rostgaard 2007; Debacker 2008; Gash 2008), as well as the complex association between attitude formation and behaviour (Steiber/Haas 2009), is underlined. Moreover, the employment status and work preferences of mothers with children under school age are found to correspond poorly in most of the countries (Beets et al. 1997; Evans/Kelley 2001; Hakovirta/Salin 2006; Wall 2007). Also, the evidence indicates that women who prefer to have one to two children usually prefer market employment, whereas women who desire larger families more often wish to concentrate on homemaking or work part-time (Lee/Gramotnev 2006). Vitali et al. (2009) in turn find that in the European countries there is an association between employment-childbearing preferences and realised fertility behaviour, whereas no link can be found between preferences and fertility intentions.

All in all, then, although it is clear that more research is needed in order to establish a detailed understanding of women's lifestyle preferences, in the light of the present evidence it appears reasonable to assume that, as suggested by Hakim, women have differing preferences when it comes to childbearing and employment. It further appears reasonable to assume that by studying these preferences it is possible to group women into the three different groups of home-centred, adaptive and work-centred. The starting point of the current framework is thus that, as suggested by Hakim, women have heterogeneous preferences. One of the strengths of this approach is that it acknowledges that women within and between the countries are not to be treated as one homogeneous group with similar kinds of desires, but that we should expect variation in the responses to, for instance, public policy. Moreover, the theory guides us in the identification of the different groups, and allows us to make suggestions about their relative size in each population.

Even though the assumption about the heterogeneity of women's preferences is warranted, the above literature overview shows that it is not obvious how strongly these preferences influence behaviour. What the findings of the cited studies do show is that women are also heterogeneous when it comes to labour market participation and to fertility. Heterogeneity of behaviour is discussed for example by Bernhardt (2000: 10), who divides women into three different groups according to their "lifetime career strategies in relation to childbearing". The first of these strategies is "career strategy", and it is chosen by women who engage in a demanding career. Given the demanding career, careerists often remain childless or only have one child. The second group of women, according to Bernhardt, chooses a "combination strategy", that is these women are interested in staying in employment, but are also willing to restrict their employment when they have children. Bernhardt further states that these women have more children if society is family-friendly. Finally, the third group of women chooses a "homemaking strategy", which means that they choose homemaking, or at least long periods of homemaking, after the first child is born. This group of women also usually has more children than those who choose the career or combination strategies.

Considering the evidence for and against the preference theory, as well as that on women's heterogeneous choices when it comes to fertility and employment, it 
appears plausible to assume that the preferred lifestyles are constrained to some degree. It can be similarly assumed that, given the constraints and preferences, women need to make different lifestyle choices when it comes to employment and fertility, and that women consequently end up with realising, at least roughly speaking, either the career strategy, the combination strategy or the homemaking strategy. These different categories proposed by Bernhardt are convenient, as the association between the different preferences and strategy groups is straightforward: Home-centred women prefer the homemaking strategy, adaptive women the combination strategy and work-centred women the career strategy. However, as the preferences remain an important determinant of lifestyle choices, it can be further postulated that when faced with constraints, and if she needs to choose a career strategy not in line with her initial preference, an individual woman will choose the strategy which bears the closest resemblance to her original desires. In other words, only in a very particular situation will, for example, a home-centered woman who cannot realise the homemaking strategy choose the career strategy instead of the combination strategy.

To understand the relations suggested above, it is helpful to think in terms of distributions (Fig. 1). What Hakim basically argues is that the range of women's preferences varies from exceptionally home-centred to exceptionally work-centred, and that three different groups of women can be distinguished within this range. According to Hakim's theory, the three different groups are sufficient to capture the most important aspects of the variation between women, but it is basically possible to divide the female population into even a larger number of groups (e.g. ten groups based on deciles). Hakim furthermore gives some loose suggestions concerning the skewness (the relative size of the different groups) of the distribution. According to her, basically any combination from a positively skewed distribution, where 30 percent of the women are home-centred women, 60 percent adaptive and 10 percent work-centred women, to a negatively skewed distribution, where 10 percent of the women are home centred, 60 percent adaptive and 30 percent work centred, is possible. However, she does not make any comments on the kurtosis (how homogeneous we can expect the women within the three different groups to be).

In a similar manner, we can understand women's career strategies as a distribution where we find women who basically never work (homemaking strategy in its extreme form) at one end and at the other those women who continuously work full-time (career strategy in its extreme form). In between these two extreme types, we find women who divide their time at home and employment differently. Unlike Hakim, Bernhardt does not make any numerical suggestions as to what the distribution of the women might look like. The shape of the distribution (that is the size of the different groups of women as well as the homogeneity within the groups), both when it comes to preferences and to career strategies, is naturally ultimately a matter for empirical investigation.

My suggestion is to link these two theories or distributions together. Were workfamily choices to be solely determined by preferences, the distribution based on preferences would be identical with the distribution based on the chosen career strategies. However, because of different constraints that limit women's opportuni- 
Fig. 1: From preferences to career strategies

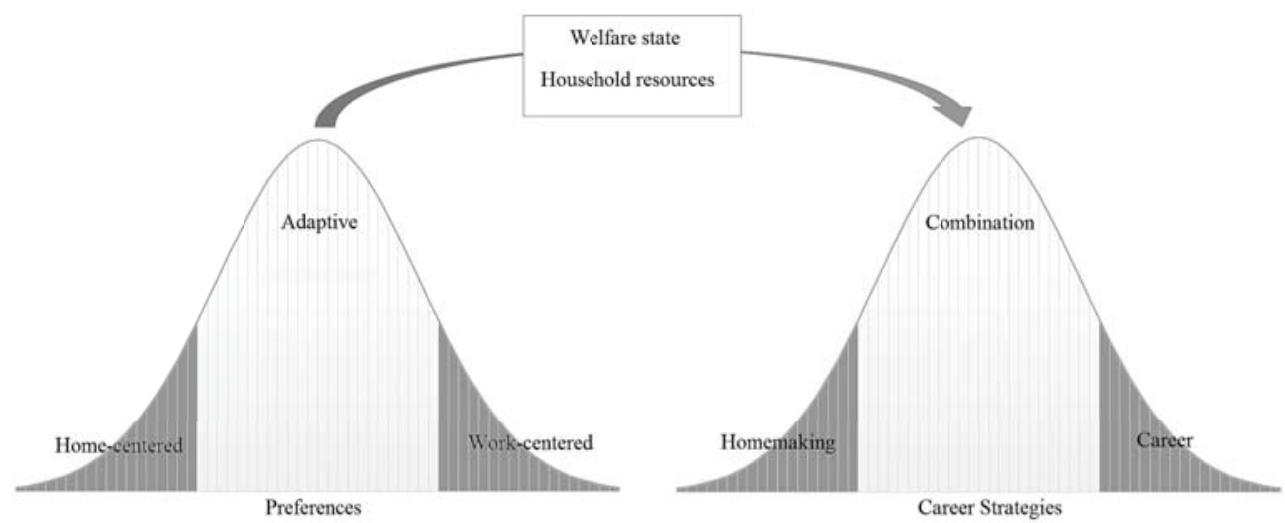

Source: own design

ties, the preference distributions and career strategy distributions are not congruent. Below I will argue that family policy as well as household resources determine the way in which the preference distribution transforms into career strategy distribution to a large extent.

\subsection{Welfare state policies, household resources and women's career strategy choices}

What kind of contextual factors help or hinder women in realising their preferences, and thus influence the way in which the preference distribution transforms to career strategy distribution? Welfare state researchers, labour market specialists and demographers have pointed out that for example the tax system (Gustafsson 1992; Dingeldey 2001; Apps/Rees 2004), parental leave regulations (Rönsen 2004; Andersson et al. 2006; Lalive/Zweimüller 2009), child care supply (Oláh 2003; Uunk et al. 2005; Baizán 2009) and the possibility to work part-time (Del Boca 2002; Lewis et al. 2008) influence women's labour market participation and fertility and shape the opportunity structures. These macro-level factors might have an impact on both the number of women who choose a certain strategy and on how the different strategies are realised. For instance, some adaptive women might see long periods of part-time work as a means to realise the combination strategy, whereas other adaptive women realise the same strategy by taking a very long parental leave. Further, as there are significant differences between the welfare states when it comes to family policy, it is reasonable to assume that in different countries the preference distributions transform to career strategy distributions differently and to a differing degree.

In addition to welfare state policies, household resources such as financial assets (wage, income, inheritance) and the number of family members and relatives who can share the burden of childcare with the mother are important for women's choices. For instance: Family income can influence the possibilities to buy good 
quality childcare, whereas care provision from family members, in turn, is particularly important for working mothers when welfare state support for childcare is inadequate or childcare is expensive. Finally, even childbearing itself can act as a constraint. Under some circumstances (e.g. expensive child care), an adaptive woman might therefore be able to realise the combination strategy by part-time work, but once she has her second child the combination becomes too costly and she has to opt for homemaking instead.

Table 3 shows data on the above variables for selected countries (except for parttime work, as indicators on part-time work measure the number of women working part-time rather than the actual availability of part-time employment). The number of full-rate equivalent parental leave weeks (column 1) and the maximum length of leave for the mother (column 2) show in particular whether and how the choices of the adaptive women, and thus the combination strategy, are supported: The longer and better compensated the leave, the better the support for the realisation of the combination strategy by long inactive periods. The shorter and more poorly compensated the leave, the more restricted the support for the combination strategy with long periods of inactivity, and the higher the incentives for a realisation of the career strategy, homemaking strategy or combination strategy with part-time work. As work-centred women who have children most likely wish to return to employment as soon as possible, the generosity or maximum length of leave periods is not likely to influence their decisions to any great extent, given that all countries provide for the possibility for at least brief leave periods. Homemakers, however, are likely to benefit from long and generous leave periods.

Enrolment in childcare for children under three years of age (column 3) as well as the average hours spent in daycare (column 4) in turn say something about the state support for adaptive and work-centred women: The higher the enrolment ratios and the number of hours in care, the better the support for the combination strategy and career strategy with children. The lower the enrolment ratios and the number of hours in care, the more incentives there are for work-centred women to stay childless. Further, the lower the enrolment ratios and hours in care, the more incentives there are for adaptive women to realise either the combination strategy by limiting their fertility (as it might be difficult to find formal or informal childcare for several children) or choose the homemaking or career strategy. In consequence, if the combination strategy is too difficult or even impossible to realise, adaptive women might need to choose between having children and remaining inactive, or not having children but work.

The structure of the tax system shows in particular whether and if so what kind of support is available for home-centred and adaptive women. The tax rate for a family where only one of the spouses is in full-time employment (column 6) is an indicator of the disposable income of the family: The lower the tax rate, the higher the disposable income of the one-earner family and the better the possibilities for homemaking or the combination strategy with long periods of inactivity. The higher the tax rate, the more pressure there is for the second earner to enter employment and thus more support for the combination strategy through part-time employment. The family privilege (column 7) is calculated by dividing the tax rate in column 6 


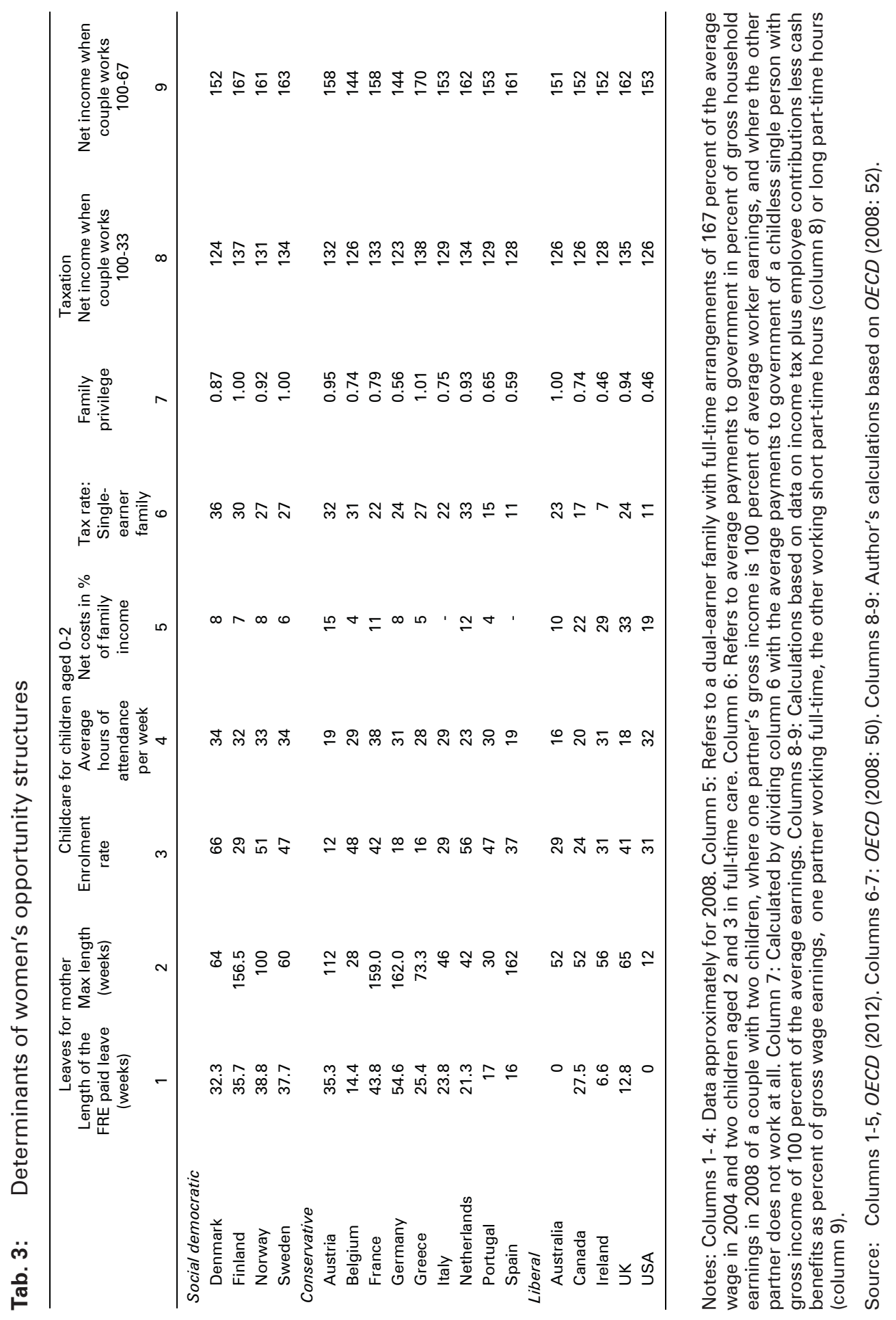


by the tax rate of a single person without children (cf. Sainsbury 1999). The closer to the unit the ratio is, the less support there is for the one-earner family model, in other words for the homemaking strategy or the combination strategy with longer employment breaks. Likewise, the further away the ratio is from the unit, the higher the support for the homemaking strategy and the combination strategy with longer breaks from employment. In addition (columns 8 and 9), following OECD (2001: 142), we take a look at how much the net income of a two-child family with average earnings (100-0) increases if the other spouse decides to work short part-time hours (100-33) or long part-time hours (100-67). The closer the net income increase is to the gross income increase (133 and 167 respectively), the more incentives there are for the second earner to enter employment, and the better the support for the realisation of the combination strategy by employment. The lower the income increase, the higher the incentives for the homemaking strategy or the combination strategy with longer inactive periods.

As to the household resources, it is difficult to find applicable macro level data and consequently only the net costs of childcare are included as a percentage of family income for a dual earner family with two children (column 5). Childcare costs are likely to give some indication of how much the strategy choices of adaptive and work-centred women in particular are influenced by household income: The higher the costs, the more likely it is that the choices are determined by income. For example, adaptive women on a low wage might be attracted to homemaking if the costs of childcare make employment unbeneficial.

The outcomes which are generated by the different opportunity structures are shown in Table 4. Even though the outlined theory concentrates on women's heterogeneity, and in essence requires to be tested with longitudinal micro level data, some trends can even be distinguished from the macro-level data. Employment patterns among couple families with youngest child aged between 3 and 5 (columns 1-4) gives information on the actual choices women make concerning employment and family. The parity-adjusted total fertility rate PATFR (or TFR), and PATFR 1 (or $T_{F}$ ) (columns 5-6) in turn indicate the level of total and first birth fertility. Finally, the proportion of live births by rank of the children (columns 7-9) sheds some further light on fertility trends.

To organise the data and the discussion, Esping-Andersen's typology is employed. As the review of the gendered welfare state literature in section 2 shows, there is no consensus on how the countries cluster in terms of family policy. However, given that the results from different studies during the past two decades overlap relatively well with Esping-Andersen's typology, his framework is employed here for its overall clarity.

\subsubsection{Social democratic countries}

In social democratic countries, family policy works in favour of the combination and career strategies at the expense of the homemaking strategy. Adaptive women can rely on the generous parental leave arrangements which enable mothers to stay home for long periods without worrying about losing their jobs (the FRE leave 
Tab. 4: Indicators of employment patterns and fertility

\begin{tabular}{|c|c|c|c|c|c|c|c|c|c|}
\hline & \multicolumn{4}{|c|}{$\begin{array}{l}\text { Employment patterns among couple families } \\
\text { when the youngest child is aged } 3-5(\%)^{\text {a }}\end{array}$} & \multicolumn{2}{|c|}{ Fertility rate } & \multicolumn{3}{|c|}{$\begin{array}{c}\text { Proportion of live } \\
\text { births by rank of } \\
\text { children }^{f}\end{array}$} \\
\hline & $\begin{array}{l}\text { Both full- } \\
\text { time }\end{array}$ & $\begin{array}{l}\text { One parent } \\
\text { full-time }\end{array}$ & $\begin{array}{l}\text { One parent } \\
\text { full-time, } \\
\text { other part- } \\
\text { time }\end{array}$ & Other & Total & First birth & 1 & 2 & $3+$ \\
\hline & 1 & 2 & 3 & 4 & 5 & 6 & 7 & 8 & 9 \\
\hline \multicolumn{10}{|c|}{ Social democratic } \\
\hline Denmark & - & - & - & - & $1.84^{\mathrm{e}}$ & - & 43 & 37 & 20 \\
\hline Finland & 63 & 19 & 12 & 7 & $1.87^{\mathrm{b}}$ & $0.79^{b}$ & 42 & 33 & 25 \\
\hline Norway & - & - & - & - & $1.98^{\mathrm{c}}$ & $0.87^{c}$ & 43 & 35 & 21 \\
\hline Sweden & 33 & 15 & 43 & 9 & $1.94^{\mathrm{b}}$ & $0.87^{b}$ & 45 & 36 & 19 \\
\hline \multicolumn{10}{|l|}{ Conservative } \\
\hline Austria & 15 & 27 & 51 & 8 & $1.41^{\mathrm{b}}$ & $0.73^{\mathrm{b}}$ & 47 & 35 & 18 \\
\hline Belgium & 32 & 23 & 36 & 9 & $1.86^{\mathrm{e}}$ & - & - & - & - \\
\hline France & 46 & 24 & 22 & 8 & $1.99^{\mathrm{e}}$ & - & - & - & - \\
\hline Germany & 13 & 30 & 47 & 10 & $1.38^{\mathrm{d}}$ & $0.68^{d}$ & $49^{d}$ & $34^{d}$ & $17^{d}$ \\
\hline Greece & 47 & 44 & 6 & 3 & $1.52^{\mathrm{c}}$ & $0.74^{c}$ & 47 & 38 & 15 \\
\hline Italy & 30 & 42 & 22 & 6 & $1.41^{\mathrm{e}}$ & - & - & - & - \\
\hline Netherlands & 4 & 20 & 62 & 14 & $1.79^{\mathrm{b}}$ & $0.83^{b}$ & 45 & 37 & 18 \\
\hline Portugal & 67 & 22 & 7 & 4 & $1.41^{\mathrm{b}}$ & $0.86^{b}$ & 53 & 35 & 11 \\
\hline Spain & 38 & 40 & 17 & 5 & $1.39^{c}$ & $0.77^{\mathrm{c}}$ & 57 & 33 & 10 \\
\hline \multicolumn{10}{|l|}{ Liberal } \\
\hline Australia & 21 & 30 & 40 & 9 & $1.90^{\mathrm{e}}$ & - & - & - & - \\
\hline Canada & - & - & - & - & $1.67^{\mathrm{b}}$ & $0.78^{b}$ & - & - & - \\
\hline Ireland & - & - & - & - & $2.07^{\mathrm{e}}$ & - & - & - & - \\
\hline UK & 19 & 28 & 43 & 11 & $1.94^{\mathrm{e}}$ & - & - & - & - \\
\hline USA & - & - & - & - & $2.14^{\mathrm{b}}$ & $0.88^{\mathrm{b}}$ & - & - & - \\
\hline
\end{tabular}

Notes: a data for approximately 2007; b data on PATFR for 2009, except for Canada and the USA for 2007; ${ }^{c}$ data on TFR for 2009; d data on TFR for 2008; ${ }^{~}$ data on TFR for 2009; f data for 2008, except for Denmark for 2005.

Source: a, e, f OECD (2012); b Human Fertility Database (2012); c author's calculations based on data from Eurostat (2012); d Kreyenfeld et al. (2010).

varies from roughly 32 weeks in Denmark to almost 39 weeks in Norway, and the time rights are even more generous, particularly in Finland and Norway). At the same time, extensive, affordable childcare ${ }^{4}$ enables mothers, regardless of their household income, to return to work without difficulties related to the organisation of childcare. Thus, adaptive women are able to combine work and the preferred number of children relatively well, even though they may face constraints such as low local availability of part-time work, which in addition to the childbearing pref-

4 Enrollment rates in Finland are considerably lower, but according to the Finnish legislation the municipalities have to organise childcare for all children below the age of three (Välimäki/Rauhala 2000). The low enrollment rates thus do not signal a limited supply, but rather a limited take-up. 
erences, the costs of children and household income limit their fertility. Furthermore, especially due to the good availability of affordable childcare work-centred women can have children without childbearing needing to interfere too much with their career plans, and consequently the level of childlessness is likely to be low. The homemaking strategy is not supported to any large extent, except for Denmark where the family privilege is relatively high and the second earner's employment is discouraged. In other countries, homemaking is costly and difficult to realise, and many home-centred women are likely to opt for the combination strategy. Those home-centred women who choose the homemaking strategy are likely to be either a group of women whose household income is high enough to enable homemaking, or whose marginal income is low, or who have very strong preferences for homemaking. For these women, as for homemakers in general, the level of fertility can be assumed (as suggested by the economic theory on fertility) to depend on childbearing preferences, on the direct costs of children, as well as on household income.

As to the outcomes, data on women's employment patterns only exist for Finland and Sweden. The relative share of mothers in employment is highest in these two countries in the cross-country comparison and the number of one earner families is the lowest. Notice, however, that it is common in Finland for both partners to work full-time, and the role of part-time work is marginal, whereas in Sweden it is almost the other way around. A somewhat larger share of women in Finland are inactive, which is likely to be due to the extensive time rights connected to leave. In other words, the data suggests that in Sweden women even realise the combination strategy often through part-time work, whereas in Finland the combination strategy is mainly realised by prolonged inactive periods followed by a return to full-time employment. As to childbearing, all four Nordic countries experience relatively high levels of fertility. However, the levels of fertility are lowest in Denmark, which disagrees with the theoretical framework given that Denmark gives the best incentives for all women to choose as they desire. The explanation of this discrepancy might be related to the lifestyle and childbearing preferences of Danish women. Rates for first birth fertility are high for both Norway and Sweden, but are considerably lower for Finland. In all countries the share of first births from the total is relatively low (from 42 percent in Finland to 45 percent in Sweden), which indicates that many women have more than only one child. Notice further that particularly in Finland the share of higher-order births is relatively high, which might be related to the higher share of inactive women: Combination through inactivity might favour larger families than combination through part-time work.

\subsubsection{Conservative countries}

There is a general bias in the conservative cluster towards the homemaking strategy, and this strategy is accordingly chosen by home-centred women as well as by many adaptive women. Homemakers are likely to have a large number of children, which means that the parity progression ratios to higher birth orders are probably higher in the conservative than in the social-democratic country cluster. Some adaptive women are able to realise the combination strategy, but need to rely extensively 
on childcare provided by their friends and relatives. Indeed, even though childcare services are relatively affordable, the scarce availability of them means that the compatibility of work and family is difficult regardless of the household income. Consequently, households resources in terms of childcare provided by relatives and friends are likely to play a crucial role. If this kind of care is not available, homemaking becomes an attractive choice. Moreover, a majority of work-centred women, as well as some adaptive women, are likely to choose the career strategy without children, which results to a relatively high degree of childlessness.

Even though a common general pattern can be identified, there is a considerable variation between the countries in how the mechanism works. Both in Austria and Germany the limited childcare supply and very long leave periods enforce and encourage homemaking, even for adaptive women. The tax system in Germany additionally reinforces the homemaking strategy, but in Austria the tax system encourages part-time work. Also in Greece, the lack of childcare enforces homemaking, but support for adaptive women is even more limited than in Austria and Germany as FRE leave is relatively short. Moreover, the tax system incentivises women's employment and leaves homemakers without support. As to the outcomes, a significantly higher share of mothers in Austria and Germany are inactive in comparison to the social democratic countries. Those women who are in employment mostly work part-time, and in accordance with the tax incentives, part-time work is somewhat more widespread in Austria than in Germany. In Greece, in turn, there is a strong polarisation between those mothers who work full-time and those who stay at home, and the role of part-time work is rather marginal. The level of total and first birth fertility is low in all countries, and the share of first-rank births is somewhat higher than in the social democratic countries. In other words, the data suggests that many women choose the career strategy without children, and those women who choose the combination strategy limit the number of children they have.

For Italy and Spain, it is primarily the restricted length of well-compensated parental leave combined with the considerable male breadwinner bias in taxation that makes homemaking beneficial for both home-centred and for adaptive women. At the same time, childcare supply is better in these countries than in Austria, Greece and Germany, which gives somewhat better possibilities for adaptive and workcentred women to live according to their preferences. As to realised behaviour, the share of inactive mothers in Italy and Spain is at the same levels as in Greece, which suggests that many women in these countries indeed relatively often opt for homemaking or the combination strategy by longer inactive periods. The share of part-time working women is lower than in Austria and Germany, whereas the share of full-time working women in turn is relatively high. Thus, whereas in Austria and Germany it is mainly the restricted supply of daycare services that force women to choose the homemaking strategy and part-time work, the somewhat better daycare supply in Italy and Spain appears to allow the women to choose the career strategy with full-time work to a larger extent, and the restricted leave periods force them to do so. Notice further that both the total and first-birth fertility rates in Spain are low, and a high share of the births are of first rank. In other words, the data suggests that 
many women choose to realise the career strategy by staying childless or by only having one child.

Portugal deviates from the patterns in these two countries. Even though family policy structures are relatively similar to those in Italy and Spain in that the leave periods are short and there is a male breadwinner bias in the tax system, the availability of daycare services is relatively good. As to the outcomes, mothers' full-time employment is even more popular in Portugal than for example in Finland and the share of inactive women is likewise at the same level as in Finland. The role of parttime work, in turn, is very marginal. Moreover, even though the level of total fertility is low, the level of first birth fertility is relatively high. Over 50 percent of the births are first births, and only 11 percent third or higher are order births. In other words, Portuguese women appear to a very large extent to choose the career strategy with only one child.

In Belgium and France, in turn, the male breadwinner bias in the tax system enables home-centred women to choose the homemaking career, but at the same time the good availability of affordable childcare in both countries and the long generous leave periods in France enable adaptive and work-centred women to choose according to their preferences. However, the length of the leave periods is more limited in Belgium, which means that Belgian adaptive women are attracted to realise the combination strategy by part-time work to a larger extent than adaptive women in France. The activity data shows that the share of inactive women is indeed slightly higher than in the social democratic countries (as the possibilities to realise the homemaking strategy are better) but lower than for example in Austria, Germany and Greece (as adaptive women are not forced to choose the homemaking strategy but have good possibilities to opt for the combination strategy). Further, the share of part-time working women is higher in Belgium than in France, which is in accordance with the family policy incentive structures. The higher share of full-time working mothers in France in turn suggests that many women realise the combination strategy by longer inactive periods and return to full-time employment. Finally, the fertility rates in both countries are at the same level as in the social democratic countries, but there is unfortunately no available good quality data on the level of first birth fertility or the distribution of the births by birth order.

In the Netherlands, there is some bias towards homemaking created by the family privilege in taxation. However, in general the tax system encourages part-time work, the relatively short leave periods provide incentives for adaptive women to realise the combination strategy by part-time work and the availability of part-time childcare is likewise relatively good. Consequently, the share of inactive mothers is somewhat lower than in Belgium and France, but still higher than in Sweden and at the same level as in Finland. However, the extremely high share of part-time working mothers (62 percent), accompanied with a very low share of full-time working mothers, cannot be explained with the incentive structures alone. One possibility is that the career strategy is not a very popular alternative among Dutch mothers, or that having children is not very popular among work-centred women. In any case, the huge popularity of the combination strategy is likely to be the main reason behind the high total and first birth fertility. 


\subsubsection{Liberal welfare states}

In the liberal countries, there is some support for each career strategy, but women's possibilities to choose according to their preferences often depend on household resources. The family taxation shapes the constraints by favouring one earner families and the homemaking strategy, which makes the homemaking strategy easily available for the home-centred women. Given the lack of well-compensated parental leave and publicly provided childcare, but the good availability of privately provided, expensive childcare, the career strategy choices of adaptive and work-centred women are likely to depend heavily on the initial resources of the family. Many adaptive women can choose the strategy they desire by buying childcare from the market (or by relying on help from their friends and relatives). For those adaptive women who cannot afford market-based childcare, or obtain help in childcare from friends and relatives, homemaking becomes an attractive alternative. Indeed, even though the enrolment rates in the liberal countries are at the same levels as in many of the conservative countries, the reason for the low enrolment is likely to be different. That is, in the conservative countries the low enrolment rates are probably due to the limited supply of public childcare, whereas in liberal countries the low enrolment rates indicate the limited take-up at current high prices. However, some adaptive women, due to the short compensated leave, might realise the combination strategy by working part-time, whereas some might even opt for the career strategy. Finally, many work-centred women are able to have children according to their preferences due to the availability of private childcare, and hence the level of childlessness is likely to be low, or in other words at the same levels as in the social democratic cluster. Consequently, the overall level of fertility is relatively high. There are some exceptions from these general patterns. Most notably, the amount of FRE leave in Canada is somewhat longer than in the other countries, the tax system in the UK encourages short part-time work rather than homemaking, and childcare costs are relatively low in Australia.

As to the outcomes, it is difficult to obtain a good picture of what is going on in the liberal countries as there is only a very limited amount of data available. The fertility rates are high in all countries except for Canada. Data on first-birth fertility is only available for Canada and the USA, and shows that part of the reason for the low Canadian total fertility is the relatively low level of first-birth fertility. On the other hand, first-birth fertility is relatively high in the USA. The data on women's employment for Australia and the UK in turn indicates that women's realised behaviour corresponds relatively well to the incentive structures. In accordance with the generous incentives for homemaking, the share of inactive women is at comparable levels to Austria and Germany for example. As could be expected based on the limited possibilities to take leave, the share of part-time working mothers is likewise relatively high and indicates that the combination strategy is often realised by parttime work. Notice furthermore that many mothers work full-time, which suggests that a relatively high share of the mothers choose the career strategy. 


\section{$5 \quad$ Previous research on fertility, family policy and women's employment revisited}

How useful is the framework outlined above when it comes to understanding the previous research on the determinants of childbearing? As to the relationship between employment and fertility, there is a relatively robust finding on the positive influence of inactivity on fertility across the welfare states (see section 3.1). This is consistent with the above framework, given that homemakers and combiners are frequently inactive for longer periods and likewise have more children than careerists. Further, the results from the meta-analysis conducted by Matysiak and Vignoli (2008) show that the negative influence of employment on childbearing increases by parity and is strongest in the liberal and conservative countries, but weaker in the social democratic countries. These too are results which we would expect based on the outlined framework. The first finding on the increases in the negative influence of employment by parity basically tells us that homemakers (who are inactive for very long periods) and combiners (who are frequently inactive for relatively long periods), have a higher propensity to continue childbearing than the careerists (who are inactive only very seldom and shorter periods) who often stay childless or have only one child. The second finding is also partly in accordance with the claim put forward above: Since the social democratic welfare states create good circumstances for combiners and careerists (that is, for working mothers) to have children, the negative effect of employment on fertility should be smaller in this country cluster than in the conservative countries.

It is further interesting that the results on the influence of part-time and full-time employment on childbearing vary depending on the welfare state. No significant differences in the impact of part-time and full-time work on childbearing is found in the social democratic context (for second and third births in Sweden, see Hoem/Hoem 1989; for second births in Sweden, see Oláh 2003; for second births in Denmark, see Brodmann et al. 2007). However, in the Netherlands (Liefbroer/Corijn 1999) as well as in Western Germany and in the UK (for second births, see Kreyenfe/d/Zabel 2005) part-time working women have a higher propensity to have children. This is consistent with the discussion above: In the Scandinavian countries where generous parental leave enable longer breaks from employment and where the daycare supply makes it possible to return to full-time employment, adaptive women realise the combination strategy both by working full-time and part-time, which might explain why no major differences are detected between part-time and full-time working women. However, in the Netherlands, Germany and the UK, where part-time work is the main means for adaptive women to realise the combination strategy and where full-time working mothers are careerists to a greater extent, it is logical that a positive influence of part-time work on fertility is found.

Concerning family policy and fertility, many studies find that childcare - regardless of the welfare state context - exerts a positive influence on fertility (see Kravdal 1996 for third births in Norway; De/ Boca 2002 for childbearing in Italy; Oláh 2003 for the intensity of second births in Sweden; Bonoli 2008 for the level of fertility in Switzerland; Baizán 2009 for first and higher order births in Spain; Rindfuss et 
al. 2010 for the level of fertility in Norway). Likewise, several studies conclude that parental leave extensions, extensions of so-called care leaves, or increases in compensation for such leave periods, have a positive impact on fertility (for the timing of third births in Austria, see Hoem et al. 2001; for the timing of second and third births in Norway, see Aassve/Lappegård 2009; for the positive effect on both tempo and quantum in Austria, see Lalive/Zweimüller 2009). Since adaptive and work-centred women are responsive to the availability of childcare, and since adaptive and home-centred women are responsive to the generosity of the parental leave, the results are consistent with the framework. Notice also that the positive influence of maternity leave extensions in Finland is found to increase by parity (Rønsen 2004). A likely reason is that extensions in the leave periods create better conditions particularly for home-centred and adaptive women, who respond by having a higher number of children, whereas work-centred women who often only have one child are not influenced by these changes due to the already good possibilities to realise the preferred strategy.

As to the domestic division of unpaid household work, there are several studies which show that a more equal division of unpaid work at home has a positive influence on fertility (for second births in the USA, see Torr/Short 2004; in Germany, see Cooke 2004; in Denmark, see Brodmann et al. 2007; in Spain and Italy, see Cooke 2008), or that the probability of continued childbearing is higher when the father takes parental leave (for second births in Sweden and Hungary, see Oláh 2003; for second and third births in Sweden, see Duvander/Andersson 2006). One interpretation of these results is that the elevated birth risks indicate a higher propensity of adaptive women to proceed to higher parities if they have a supportive spouse who helps them to realise their preferences smoothly. However, Torr and Short (2004) report that those families where the women do a large majority of the household work also have a higher propensity of second births, and Cooke (2004) shows that the more the women spend time on childcare, the higher the risk of second birth. In other words, these results indicate that homemakers who are likely to spend most time on household responsibilities have higher propensity to continue to higher parities. Further, Duvander and Andersson (2006) point out that the risk of a birth in terms of mother's parental leave take is inverted U-shaped for the second births (e.g. the risk is lowest for those mothers who take out least and most leave) and J-shaped for third births. The low propensity of second births for mothers who only take short leave periods in connection with their first birth can probably be attributed to the careerists, who are likely to take the shortest leaves and often have only one child. Likewise, the J-shaped pattern for third births clearly indicates that homemakers and combiners who are likely to take the longest leave also have the highest propensity to continue to higher parities. However, it is not clear why long leave periods in connection with the first birth would lead to a lower propensity of second births, or why short leave periods in connection with the second birth would lead to a higher propensity of third births. 


\section{Concluding remarks}

In the first part of the paper, I discussed some ways in which demographers may benefit from gendered research on the welfare state. However, many perspectives on fertility which, for example, emphasise the role of values (van de Kaa 1987, 2002; Lestaeghe/Surkyn 2004), as well as the way in which past fertility and population structures influence current fertility ideals and decisions (Lutz/Skirbekk 2005; Lutz et al. 2006) were excluded from this overview. Thus, in addition to the above mentioned topics and subjects, there might be several other ways in which demographers will find the research conducted by welfare state researchers beneficial. Further, the above review is relatively rough, and future contributions on the topic should be more detailed. Finally, it needs to be pointed out that even though the current paper concentrates on the lessons that demographers might be able to derive from welfare state research, an equally important question is naturally what welfare state researchers can learn from demographers. All in all, a further discussion between these two disciplines is recommended.

The second part of the paper outlined a new framework which emphasises the role of preferences, family policy and household resources in women's decision making. In other words, the framework only concentrated on a handful of variables, even though the research on the determinants of fertility has identified even several other variables which are at play when decisions about childbearing are made. However, individual level variables such as values (van de Kaa 2001), number of own siblings (Murphy/Knudsen 2002; Kreyenfeld 2004), own (Adsera 2006) and parents' religion (Branas-Garza/Neuman 2006; Berghammer 2009), as well as other similar attributes which are found to influence fertility, might partly operate through preferences by having an impact on women's lifestyle desires. Other factors, for instance the level (Kreyenfeld 2002, 2004) and field (Hoem et al. 2006a/b) of education, which have an impact on fertility, might in turn be determined at least to a certain degree by lifestyle preferences. Finally, some factors, such as difficulties to find a spouse (Tanturri/Mencarini 2008), infertility or conflicting preferences on the number of children with the spouse (Voas 2003) naturally also influence the individual women's choices, and may even add to substantial patterns in the overall population. However, not all women do face these problems and circumstances, but all women make their choices within those structures which are determined by family policy and household resources. To put it differently, the point I want to make here is that in order to understand the cross-country differences in fertility we need to recognise the heterogeneous preferences of women, understand how the contextual factors shape women's lives and carefully study how the preferences transform into choices. How other variables relate to this "big picture" is not unimportant, but it is unlikely that factors such as choices about educational field or conflicting preferences with the spouse would be significantly different or more common in some countries than in others, and such variables are thus likely to have less explanatory power on fertility differences between the countries. 


\section{Acknowledgements}

This paper is a revised version of a chapter in my dissertation at Heidelberg University. I would like to thank my supervisor Prof. Uwe Wagschal for his valuable advice, and two anonymous reviewers for their helpful comments and suggestions. The paper has also greatly benefited from discussions with Thomas Metz.

\section{References}

Aassve, Arnstein; Lappegård, Trude 2009: Childcare Cash Benefits and Fertility Timing in Norway. In: European Journal of Population 25,1: 67-88 [doi: 10.1007/ s10680-008-9158-6].

Adsera, Alicia 2006: Religion and changes in family-size norms in developed countries. In: Review of Religious Research 47,3: 271-286.

Ahn, Namkee; Mira, Pedro 2002: A note on the changing relationship between fertility and female employment rates in developed countries. In: Journal of Population Economics 15,4: 667-682 [doi: 10.1007/s001480100078].

Andersson, Gunnar 2000: The Impact of Labour-Force Participation on Childbearing Behaviour: Pro-Cyclical Fertility in Sweden during the 1980s and the 1990s. In: European Journal of Population 16,4: 293-333 [doi: 10.1023/A:1006454909642].

Andersson, Gunnar; Hoem, Jan M.; Duvander, Ann-Zofie 2006: Social differentials in speed-premium effects in childbearing in Sweden. In: Demographic Research 14,4: 51-70 [doi: 10.4054/DemRes.2006.14.4].

Anttonen, Anneli; Sipilä, Jorma 1996: European Social Care Services: Is it Possible To Identify Models? In: Journal of European Social Policy 6,2: 87-100 [doi: 10.1177/095892879600600201].

Apps, Patricia; Rees, Ray 2004: Fertility, Taxation and Family Policy. In: Scandinavian Journal of Economics 106,4: 745-763 [doi: 10.1111/j.0347-0520.2004.00386.x].

Arts, Wilhelmus Antonius; Gelissen, John 2002: Three worlds of welfare capitalism or more? A state-of-the-art report. In: Journal of European Social Policy 12,2: 137-158 [doi: 10.1177/0952872002012002114].

Baizán, Pau 2009: Regional child care availability and fertility decisions in Spain. In: Demographic Research 21: 803-842 [doi: 10.4054/DemRes.2009.21.27].

Becker, Gary S. 1960: An Economic Analysis of Fertility. In: Demographic and Economic Change in Developed Countries. National Bureau of Economic Research, conference series 11. Princeton, N.J.: Princeton University Press: 209-231.

Becker, Gary S. 1981/1991: A Treatise on the Family. Cambridge MA: Harvard University Press.

Becker, Gary S.; Lewis, H. Gregg 1973: On the Interaction between the Quantity and Quality of Children. In: The Journal of Political Economy 81,2: 279-288.

Beets, Gijs C.N.; Liefbroer, Aart C.; Jong Gierveld, Jenny de 1997: Combining employment and parenthood: A longitudinal study of intentions of Dutch young adults. In: Population Research and Policy Review 16,5: 457-474 [doi: 10.1023/A:1005895302226].

Berghammer, Caroline 2009: Religious Socialisation and Fertility: Transition to Third Birth in The Netherlands. In: European Journal of Population 25,3: 297-324 [doi: 10.1007/s10680-009-9185-y]. 
Berinde, Diana 1999: Pathways to a Third Child in Sweden. In: European Journal of Population 15,4: 349-378 [doi: 10.1023/A:1006287630064].

Bernhardt, Eva M. 2000: Female Careers between Employment and Children. Paper presented at the seminar "Low fertility, families and public policies", organized by the European Observatory on Family Matters in Sevilla, September 15.-16. 2000.

Bettio, Francesca; Plantenga, Janneke 2004: Comparing care regimes in Europe. In: Feminist Economics 10,1: 85-113 [doi: 10.1080/1354570042000198245].

Bonoli, Giuliano 2008: The impact of social policy on fertility: evidence from Switzerland. In: Journal of European Social Policy 18,1: 64-77 [doi: 10.1177/0958928707081074].

Borchorst, Anette; Siim, Birte 2008: Woman-friendly policies and state feminism: Theorizing Scandinavian gender equality. In: Feminist Theory 9,2: 207-224 [doi: 10.1177/1464700108090411].

Brañas-Garza, Pablo; Neuman, Shoshana 2006: Is Fertility Related to Religiosity? Evidence from Spain. IZA Discussion Paper No. 2192 [http://hdl.handle.net/10419/34105, 14.10.2013].

Breton, Didier; Prioux, France 2009: The one-child family: France in the European context. In: Demographic Research 20,27: 657-692 [doi: 10.4054/DemRes.2009.20.27].

Brewster, Karin L.; Rindfuss, Ronald R. 2000: Fertility and women's employment in industrialized nations. In: Annual Review of Sociology 26: 271-296 [doi: 10.1146/annurev. soc.26.1.271].

Brodmann, Stefanie; Esping-Andersen, Gøsta; Güell, Maia 2007: When Fertility is Bargained: Second Births in Denmark and Spain. In: European Sociological Review 23,5: 599-613 [doi: 10.1093/esr/jcm025].

Castles, Francis G. 2003: The World Turned Upside Down: Below Replacement Fertility, Changing Preferences and Family-Friendly Public Policy in 21 OECD Countries. In: Journal of European Social Policy 13,3: 209-227 [doi: 10.1177/09589287030133001].

Cooke, Lynn Prince 2004: The Gendered Division of Labor and Family Outcomes in Germany. In: Journal of Marriage and Family 66,5: 1246-1259 [doi: 10.1111/j.00222445.2004.00090.x].

Cooke, Lynn Prince 2008: Gender Equity and Fertility in Italy and Spain. In: Journal of Social Policy 38,1: 123-140 [doi: 10.1017/S0047279408002584].

Crompton, Rosemary; Harris, Fiona 1998a: Explaining Women's Employment Patterns: 'Orientations to Work' Revisited. In: The British Journal of Sociology 49,1: 118-136 [http://www.jstor.org/stable/591266, 14.10.2013].

Crompton, Rosemary; Harris, Fiona 1998b: A Reply to Hakim. In: The British Journal of Sociology 49,1: 144-149.

Crompton, Rosemary; Lyonette, Clare 2005: The new gender essentialism - domestic and family 'choices' and their relation to attitudes. In: The British Journal of Sociology 56,4: 601-620 [doi: 10.1111/j.1468-4446.2005.00085.x]

Daly, Mary; Lewis, Jane 2000: The concept of social care and the analysis of contemporary welfare states. In: British Journal of Sociology 51,2: 281-298 [doi: 10.1111/j.14684446.2000.00281.x].

De Henau, Jérôme; Meulders, Danièle; O'dorchai, Síle 2006: The childcare triad? Indicators assessing three fields of child policies for working mothers in the EU-15. In: Journal of Comparative Policy Analysis: Research and Practice 8,2: 129-148 [doi: 10.1080/13876980600682162]. 
Debacker, Maja 2008: Care strategies among high- and low-skilled mothers: a world of difference? In: Work, employment and society 22,3: 527-545 [doi: 10.1177/0950017008093476].

Del Boca, Daniela 2002: The effect of child care and part time opportunities on participation and fertility decisions in Italy. In: Journal of Population Economics 15,3: 549-573 [doi: 10.1007/s001480100089].

Dingeldey, Irene 2001: European Tax Systems and their Impact on Family Employment Patterns. In: Journal of Social Policy 30,4: 653-672.

Doorewaard, Hans; Hendrickx, John; Verschuren, Piet 2004: Work Orientations of Female Returners. In: Work, employment and society 18,1: 7-27 [doi: 10.1177/0950017004038387].

Duvander, Ann-Zofie; Andersson, Gunnar 2006: Gender Equality and Fertility in Sweden: A Study on the Impact of the Father's Uptake of Parental Leave on Continued Childbearing. In: Marriage and Family Review 39,1/2: 121-142 [doi: 10.1300/J002v39n01_07].

Esping-Andersen, Gøsta 1990: The Three Worlds of Welfare Capitalism. Cambridge: Policy Press.

Esping-Andersen, Gøsta 1999: The Household Economy. In: Esping-Andersen, Gøsta (Ed.): Social Foundations of Postindustrial Economies. Oxford University Press [doi: 10.1093/0198742002.003.0004].

Eurostat 2012: New Cronos Database [doi: 10.5257/eurostat/nc/2012-04-25].

Evans, M.D.R.; Kelley, Jonathan 2001: Employment for mothers of pre-school children: Evidence from Australia and 23 other nations. In: People and Place 9,3: 28-40.

Fagnani, Jeanne 2007: Fertility Rates and Mothers' Employment Behaviour in Comparative Perspective: Similarities and Differences in Six European Countries. In: Crompton, Rosemary; Lewis, Suzan; Lyonette, Clare (Eds.): Women, Men, Work and Family in Europe. Palgrave Macmillan.

Fraser, Nancy 1994: After the Family Wage: Gender Equity and the Welfare State. In: Political Theory 22,4: 591-618 [doi: 10.1177/0090591794022004003].

Gash, Vanessa 2008: Preference or constraint? Part-time workers' transitions in Denmark, France and the United Kingdom. In: Work, employment and society 22,4: 655-674 [doi: 10.1177/0950017008096741].

Gauthier, Anne H. 2007: The Impact of family policies on fertility in industrialized countries: a review of the literature. In: Population Research and Policy Review 26,3: 323-346 [doi: 10.1007/s11113-007-9033-x].

González, María-José; Jurado-Guerrero, Teresa 2006: Remaining childless in affluent economies: a comparison of France, West Germany, Italy and Spain, 1994-2001. In: European Journal of Population 22,4: 317-352 [doi: 10.1007/s10680-006-9000-y].

Gustafsson, Siv 1992: Separate taxation and married women's labor supply. A comparison of West Germany and Sweden. In: Journal of Population Economics 5,1: 61-85 [doi: 10.1007/BF00160329].

Hakim, Catherine 1998: Developing a Sociology for the Twenty-First Century: Preference Theory. In: The British Journal of Sociology 49,1: 137-143 [doi: 10.2307/591267].

Hakim, Catherine 2000: Work-Lifestyle Choices in the 21st Century: Preference Theory. Oxford: Oxford University Press.

Hakim, Catherine 2002: Lifestyle Preferences as Determinants of Women's Differentiated Labor Market Careers. In: Work and Occupations 29,4: 428-459 [doi: $10.1177 / 0730888402029004003]$. 
Hakim, Catherine 2003a: A New Approach to Explaining Fertility Patterns: Preference Theory. In: Population and Development Review 29,3: 349-374 [doi: 10.1111/j.17284457.2003.00349.x].

Hakim, Catherine 2003b: Models of the Family in Modern Societies: Ideals and Realities. Aldershot: Ashgate.

Hakim, Catherine 2003c: Public morality versus personal choice: the failure of social attitude surveys. in: British Journal of Sociology 54,3: 339-345 [doi: 10.1111/j.14684446.2003.00339.x].

Hakovirta, Mia; Salin, Milla 2006: Valinta vai pakko? Kansainvälinen vertailu äitien preferoiman ja toteutuneen työmarkkina-aseman yhteydestä. In: Janus 14,3: 255-271.

Henninger, Annette; Wimbauer, Christine; Dombrowski, Rosine 2008: Demography as a Push toward Gender Equality? Current Reforms of German Family Policy. Social Politics 15,3: 287-314 [doi: 10.1093/sp/jxn015].

Hernes, Helga Maria 1987/1989: Wohlfahrtsstaat und Frauenmacht. Essays über die Feminisierung des Staates. Baden-Baden: Nomos.

Hoem, Britta 2000: Entry into motherhood in Sweden: the influence of economic factors on the rise and fall in fertility, 1986-1997. In: Demographic Research 2 [doi: 10.4054/ DemRes.2000.2.4].

Hoem, Britta; Hoem, Jan M. 1989: The Impact of Women's Employment on Second and Third Births in Modern Sweden. In: Population Studies 43,1: 47-67 [doi: 10.1080/0032472031000143846].

Hoem, Jan M.; Neyer, Gerda; Andersson, Gunnar 2006a: Education and childlessness. The relationship between educational field, educational level, and childlessness among Swedish women born in 1955-59. In: Demographic Research 14,15: 331-380 doi: 10.4054/DemRes.2006.14.15].

Hoem, Jan M.; Neyer, Gerda; Andersson, Gunnar 2006b: Educational attainment and ultimate fertility among Swedish women born in 1955-59. In: Demographic Research 14,16: 381-404 [doi: 10.4054/DemRes.2006.14.16].

Hoem, Jan M.; Prskawetz, Alexia; Neyer, Gerda 2001: Autonomy or conservative adjustment? The effect of public policies and educational attainment on third births in Austria, 1975-96. In: Population Studies 55,3: 249-261 [doi: 10.1080/00324720127700].

Human Fertility Database 2012: Max Planck Institute for Demographic Research (Germany) and Vienna Institute of Demography (Austria) [URL: www.humanfertility.org, March-May 2012].

Kan, Man Yee 2007: Work Orientation and Wives' Employment Careers: An Evaluation of Hakim's Preference Theory. In: Work and Occupations 34,4: 430-462 [doi: 10.1177/0730888407307200].

Kangas, Olli; Rostgaard, Tine 2007: Preferences or institutions? Work family life opportunities in seven European countries. In: Journal of European Social Policy 17,3: 240-256 [doi: 10.1177/0958928707078367].

Klein, Thomas; Eckhard, Jan 2007: Educational Differences, Value of Children and Fertility Outcomes in Germany. In: Current Sociology 55,4: 505-525 [doi: 10.1177/0011392107077636].

Knijn, Trudie; Ostner, Ilona 2002: Commodification and de-commodification. In: Hobson, Barbara; Lewis, Jane; Siim, Birte (Eds.): Contested concepts in gender and social politics. Cheltenham: Edward Elgar.

Köppen, Katja 2006: Second births in western Germany and France. In: Demographic Research 14: 295-330 [doi: 10.4054/DemRes.2006.14.14]. 
Kravdal, Øystein 1996: How the local supply of day-care centers influences fertility in Norway: A parity-specific approach. In: Population Research and Policy Review 15,3: 201-218 [doi: 10.1007/BF00127049].

Kreyenfeld, Michaela 2002: Time-squeeze, partner effect or self-selection? An investigation into the positive effect of women's education on second birth risks in West Germany. In: Demographic Research 7: 15-48 [doi: 10.4054/DemRes.2002.7.2].

Kreyenfeld, Michaela 2004: Fertility Decisions in the FRG and GDR: An Analysis with Data from the German Fertility and Family Survey. In: Demographic Research, Special collection 3,11: 276-318 [doi: 10.4054/DemRes.2004.S3.11].

Kreyenfeld, Michaela; Zabel, Cordula 2005: Female Education and the Second Child: Great Britain and Western Germany Compared. Schmollers Jahrbuch. Zeitschrift für Wirtschafts- und Sozialwissenschaften 125,1: 145-156.

Kreyenfeld, Michaela; Scholtz, Rembrandt; Peters, Frederik; Wlosnewski, Ines 2010: Order-Specific Fertility Rates for Germany Estimates from Perinatal Statistics for the Period 2001-2008. In: Comparative Population Studies - Zeitschrift für Bevölkerungswissenschaft 35,2: 207-224 [doi: 10.4232/10.CPoS-2010-06en].

Lalive, Rafael; Zweimüller, Josef 2009: How does parental leave affect fertility and return to work? Evidence from two natural experiments. In: The Quarterly Journal of Economics 124,3: 1363-1402 [doi: 10.1162/qjec.2009.124.3.1363].

Lee, Christina; Gramotnev, Helen 2006: Motherhood Plans among Young Australian Women: Who Wants Children These Days? In: Journal of Health Psychology 11,1: 5-20 [doi: 10.1177/1359105306058838].

Leitner, Andrea; Wroblewski, Angela 2006: Welfare states and work-life balance. In: European Societies 8,2: 295-317 [doi: 10.1080/14616690600645092].

Leitner, Sigrid 2003: Varieties of Familialism. The caring function of the family in comparative perspective. In: European Societies 5,4: 353-375 [doi: 10.1080/ 1461669032000127642].

Leitner, Sigrid; Lessenich, Stephan 2007: (In)Dependence as dependent variable: conceptualizing and measuring 'de-familialization'. In: Clasen, Jochen; Siegel, Nico A. (Eds.): Investigating Welfare State Change. The 'Dependent Variable Problem' in Comparative Analysis. Cheltenham: Edward Elgar [doi: 10.4337/9781847206916.00022].

Lesthaeghe, Ron; Surkyn, Johan 2004: When History moves on: The Foundations and Diffusion of a Second Demographic Transition. Seminar on Ideational Perspectives on International Family Change, Population Studies Center, Institute for Social Research (ISR). University of Michigan, Ann Arbor MI, June 2004.

Lewis, Jane, 1992: Gender and the Development of Welfare Regimes. In: Journal of European Social Policy 2,3: 159-173 [doi: 10.1177/095892879200200301].

Lewis, Jane, 1997: Gender and Welfare Regimes: Further Thoughts. In: Social Politics 4,2:160-177 [doi: 10.1093/sp/4.2.160].

Lewis, Jane; Campbell, Mary; Huerta, Carmen 2008: Patterns of paid and unpaid work in Western Europe: gender, commodification, preferences and the implications for policy. In: Journal of European Social Policy 18,1: 21-37 [doi: 10.1177/0958928707084450].

Liefbroer, Aart C.; Corijn, Martine 1999: Who, What, Where, and When? Specifying the Impact of Educational Attainment and Labour Force Participation on Family Formation. In: European Journal of Population 15,1: 45-75 [doi: 10.1023/A:1006137104191].

Lister, Ruth 1994: She has other duties - Women, citizenship and social security. In: Baldwin, Sally; Falkingham, Jane (Eds.): Social Security and Social Change: New Challenges to the Beveridge Model. New York: Harvester Wheatsheaf. 
Lutz, Wolfgang; Skirbekk, Vegard 2005: Policies Addressing the Tempo Effect in LowFertility Countries. In: Population and Development Review 31,4: 699-720 [doi: 10.1111/j.1728-4457.2005.00094.x].

Lutz, Wolfgang; Skribekk, Vegard; Testa, Maria Rita 2006: The Low-Fertility Trap Hypothesis: Forces that May Lead to Further Postponement and Fewer Births in Europe. In: Vienna Yearbook of Population Research 2006: 167-192 [doi: 10.1553/populationyearbook2006s167].

Matysiak, Anna; Vignoli, Daniele 2008: Fertility and Women's Employment: A Metaanalysis. In: European Journal of Population 24,4: 363-384.

Mazur, Amy G. 2002: Theorizing feminist policy. Oxford: Oxford University Press [doi: 10.1093/0199246726.001.0001].

McDaniel, Susan A. 1996: Toward a Synthesis of Feminist and Demographic Perspectives on Fertility. In: The Sociological Quarterly 37,1: 83-104 [doi: 10.1111/j.1533-8525.1996. tb02332.x].

McDonald, Peter 2000a: Gender Equity, Social Institutions and the Future of Fertility. In: Journal of Population Research 17,1: 1-16 [doi: 10.1007/BF03029445]

McDonald, Peter 2000b: Gender Equity in Theories of Fertility Transition. In: Population and Development Review 26,3: 427-439 [doi: 10.1111/j.1728-4457.2000.00427.x].

McDonald, Peter 2002: Sustaining Fertility through Public Policy: The Range of Options. In: Population, English Edition 57,3: 417-446 [doi: 10.2307/3246634].

McLaughlin, Eithne; Glendinning, Caroline 1994: Paying for Care in Europe: Is There a Feminist Approach? In: Hantrais, Linda; Mangen, Steen (Eds.): Family Policy and the Welfare of Women. Cross-National Research Papers. University of Loughborough.

McRae, Susan 2003a: Constraints and choices in mothers' employment careers: a consideration of Hakim's Preference Theory. In: The British Journal of Sociology 54,3: 317-338 [doi: 10.1111/j.1468-4446.2003.00317.x].

McRae, Susan 2003b: Choice and constraints in mothers' employment careers: McRae replies to Hakim. In: The British Journal of Sociology 54,4: 585-592 [doi: 10.1111/j.14684446.2003.00585.x].

Murphy, Michael; Knudsen, Lisbeth B. 2002: The intergenerational transmission of fertility in contemporary Denmark: The effects of number of siblings (full and half), birth order, and whether male or female. In: Population Studies 56,3: 235-248 [doi: 10.1080/00324720215937].

Neyer, Gerda 2006: Family policies and fertility in Europe: Fertility policies at the intersection of gender policies, employment policies and care policies. MPIDR Working Paper WP 2006-010 [URL: http://www.demogr.mpg.de/papers/working/wp-2006-010. pdf, 15.10.2013].

Neyer, Gerda 2011: Should governments in Europe be more aggressive in pushing for gender equality to raise fertility? The second "NO". In: Demographic Research 24,10: 225-250 [doi: 10.4054/DemRes.2011.24.10].

Obinger, Herbert; Wagschal, Uwe 1998: Drei Welten des Wohlfahrtsstaates? Das Stratifizierungskonzept in der clusteranalytischen Überprüfung. In: Lessenich, Stephan; Ostner, Ilona (Eds.): Welten des Wohlfahrtskapitalismus. Der Sozialstaat in vergleichender Perspektive. Frankfurt a.M.: Campus.

OECD 2001: Employment Outlook 2001 [doi:10.1787/empl_outlook-2001-en].

OECD 2008: Taxing Wages 2007-2008. Paris: OECD. 
OECD 2012: Family Database. Paris: OECD [URL: http://www.oecd.org/els/soc/oecdfamilydatabase.htm, 15.10.2013]

Oláh, Livia Sz. 2003: Gendering fertility: Second births in Sweden and Hungary. In: Population Research and Policy Review 22,2: 171-200 [doi: 10.1023/A:1025089031871].

Orloff, Ann Shola 1993: Gender and the Social Rights of Citizenship: The Comparative Analysis of Gender Relations and Welfare States. In: American Sociological Review 58,3: 303-328 [doi: 10.2307/2095903].

Ostner, Ilona 1995: Arm ohne Ehemann? Sozialpolitische Regulierung von Lebenschancen für Frauen im internationalen Vergleich. In: Aus Politik und Zeitgeschichte 36/37: 3-12.

Pfau-Effinger, Birgit 2004: Development of culture, welfare states and women's employment in Europe. Aldershot: Ashgate.

Pfau-Effinger, Birgit 2005: Welfare state policies and the development of care arrangements. In: European Societies 7,2: 321-347 [doi: 10.1080/14616690500083592].

Prskawetz, Alexia; Zagaglia, Barbara 2005: Second Births in Austria. In: Vienna Yearbook of Population Research 2005: 143-170 [doi: 10.1553/populationyearbook2005s143].

Rindfuss, Ronald R.; Brewster, Karin L. 1996: Childrearing and Fertility. In: Population and Development Review 22: 258-289 [doi: 10.2307/2808014].

Rindfuss, Ronald R.; Guzzo, Karen Benjamin; Morgan, S. Philip 2003: The changing institutional context of low fertility. In: Population Research and Policy Review 22,5-6: 411-438 [doi: 10.1023/B:POPU.0000020877.96401.b3].

Rindfuss, Ronald R.; Guilkey, David K.; Morgan, S. Philip; Kravdal, Øystein 2010: ChildCare Availability and Fertility in Norway. In: Population and Development Review 36,4: 725-748 [doi: 10.1111/j.1728-4457.2010.00355.x].

Rondinelli, Concetta; Aassve, Arnstein; Billari, Fransesco C. 2010: Women's wages and childbearing decisions: Evidence from Italy. In: Demographic Research 22: 549-578 [doi: 10.4054/DemRes.2010.22.19].

Rønsen, Marit 2004: Fertility and Public Policies - Evidence from Norway and Finland. In: Demographic Research 10,6: 143-170 [doi: 10.4054/DemRes.2004.10.6].

Sainsbury, Diane 1994: Gendering Welfare States. London: Sage. [doi: 10.4135/9781446250518].

Sainsbury, Diane 1999: Taxation, Family Responsibilities, and Employment. In: Sainsbury, Diane (Ed.): Gender and Welfare State Regimes. Oxford: Oxford University Press [doi: 10.1093/0198294166.003.0007].

Steiber, Nadia; Haas, Barbara 2009: Ideals or compromises? The attitude-behaviour relationship in mothers' employment. In: Socio-Economic Review 7,4: 639-668 [doi: 10.1093/ser/mwp015].

Tanturri, Maria Letizia; Mencarini, Letizia 2008: Childless or Childfree? Paths to Voluntary Childlessness in Italy. In: Population and Development Review 34,1: 51-77 [doi: 10.1111/j.1728-4457.2008.00205.x]

Thévenon, Olivier 2011: Family Policies in OECD Countries: A Comparative Analysis. In: Population and Development Review 37.1: 57-87 [doi: 10.1111/j.17284457.2011.00390.x].

Torr, Berna Miller; Short, Susan E. 2004: Second Births and the Second Shift: A Research Note on Gender Equity and Fertility. In: Population and Development Review 30,1: 109-130 [doi: 10.1111/j.1728-4457.2004.00005.x]. 
UN (United Nations) 2010: World Population Policies 2009. New York: United Nations Department of Economic and Social Affairs/Population Division.

Uunk, Wilfred; Kalmijn, Matthijs; Muffels, Ruud 2005: The Impact of Young Children on Women's Labour Supply. A Reassessment of Institutional Effects in Europe. In: Acta Sociologica 48,1: 41-62 [doi: 10.1177/0001699305050986].

Välimäki, Anna-Leena; Rauhala, Pirkko-Liisa 2000: Lasten päivähoidon taipuminen yhteiskunnallisiin murroksiin Suomessa. In: Yhteiskuntapolitiikka 65,5: 387-405.

van de Kaa, Dirk J. 1987: Europe's Second Demographic Transition. In: Population Bulletin 42,1: 1-57.

van de Kaa, Dirk J. 2001: Postmodern Fertility Preferences: From Changing Value Orientation to New Behavior. In: Population and Development Review 27: 290-331.

van de Kaa, Dirk J. 2002: The Idea of a Second Demographic Transition in Industrialized Countries. Paper presented at the Sixth Welfare Policy Seminar of the National Institute of Population and Social Security. Tokyo, Japan, 29 January 2002.

Vikat, Andres 2004: Women's Labor Force Attachment and Childbearing in Finland. In: Demographic Research, Special Collection 3;8: 177-212 [doi: 10.4054/DemRes.2004. S3.8]:

Vitali, Agnese; Billari, Francesco C.; Prskawetz, Alexia; Testa, Maria Rita 2009: Preference Theory and Low Fertility: A Comparative Perspective. In: European Journal of Population 25,4: 413-438 [doi: 10.1007/s10680-009-9178-x].

Voas, David 2003: Conflicting Preferences: A Reason Fertility Tends to Be Too High or Too Low. In: Population and Development Review 29,4: 627-646 [doi: 10.1111/j.17284457.2003.00627.x]

Wall, Karin 2007: Main Patterns in Attitudes to the Articulation Between Work and Family Life: A Cross-National Analysis. In: Crompton, Rosemary; Lewis, Suzan; Lyonette, Clare (Eds): Women, Men, Work and Family in Europe. Palgrave Macmillan.

Westoff, Charles F.; Marshall, Emily A. 2010: Hispanic Fertility, Religion and Religiousness in the U.S. In: Population Research and Policy Review 29,4: 441-452 [doi: 10.1007/ s11113-009-9156-3].

Willis, Robert J. 1973: A New Approach to the Economic Theory of Fertility Behavior. In: Journal of Political Economy 81,2: 14-64 [doi: 10.1086/260152].

Woods, Dorian R. 2006: Focusing on Care: Family Policy and Problems of Analysis. WiP Working Paper Series, paper number 30. Institute of Political Science. University of Tübingen. 
A German translation of this reviewed and author's authorised original article by the Federal Institute for Population Research is available under the title "Fertilität, Familienpolitik und Wohlfahrtsregime", DOI 10.12765/CPoS-2013-18de or URN urn:nbn:de:bib-cpos-2013-18de7, at http://www. comparativepopulationstudies. de.

Date of submission: 19.11.2011

Date of acceptance: 19.11.2012

Elina Schleutker $(\bowtie)$. Albert-Ludwigs-Universität Freiburg, Seminar für Wissenschaftliche Politik, Freiburg, Germany. E-Mail: elina.schleutker@politik.uni-freiburg.de,

URL: http://portal.uni-freiburg.de/politik/professuren/vergleichende-regierungslehre/ mitarbeiter/schleutker-elina?set_language $=$ de 


\section{Comparative Population Studies}

WWW.comparativepopulationstudies.de

ISSN: 1869-8980 (Print) - 1869-8999 (Internet)

Published by / Herausgegeben von

Prof. Dr. Norbert F. Schneider

Federal Institute for Population Research

D-65180 Wiesbaden / Germany

Managing Editor /

Verantwortlicher Redakteur

Frank Swiaczny

Assistant Managing Editor /

Stellvertretende Redakteurin

Katrin Schiefer

Language \& Copy Editor (English) /

Lektorat \& Übersetzungen (englisch)

Amelie Franke

\section{Copy Editor (German) /}

Lektorat (deutsch)

Dr. Evelyn Grünheid

\section{Layout / Satz}

Beatriz Feiler-Fuchs

E-mail:cpos@bib.bund.de

\author{
Scientific Advisory Board / \\ Wissenschaftlicher Beirat \\ Paul Gans (Mannheim) \\ Johannes Huinink (Bremen) \\ Michaela Kreyenfeld (Berlin) \\ Marc Luy (Wien) \\ Clara H. Mulder (Groningen) \\ Notburga Ott (Bochum) \\ Peter Preisendörfer (Mainz) \\ Zsolt Spéder (Budapest)
}

\section{Board of Reviewers / Gutachterbeirat} Martin Abraham (Erlangen) Laura Bernardi (Lausanne) Hansjörg Bucher (Bonn) Claudia Diehl (Konstanz) Andreas Diekmann (Zürich) Gabriele Doblhammer-Reiter (Rostock) E.-Jürgen Flöthmann (Bielefeld) Alexia Fürnkranz-Prskawetz (Wien) Beat Fux (Zürich) Joshua Goldstein (Rostock) Karsten Hank (Köln) Sonja Haug (Regensburg) Aart C. Liefbroer (Den Haag) Kurt Lüscher (Konstanz) Dimiter Philipov (Wien) Tomáš Sobotka (Wien) Heike Trappe (Rostock) 